INSIGHTS INTO REGIONAL DEVELOPMENT

ISSN 2669-0195 (online) http://jssidoi.org/IRD/

2019 Volume 1 Number 4 (December)

http://doi.org/10.9770/IRD.2019.1.4(4)

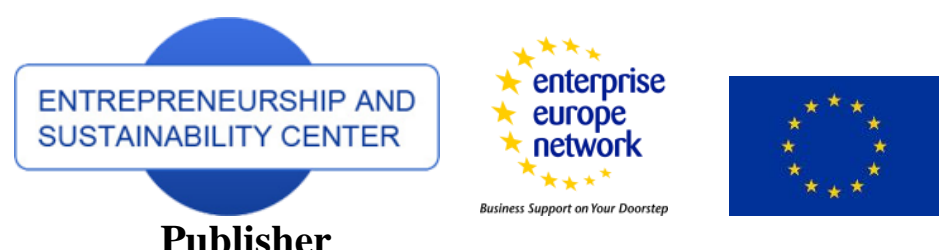

http://jssidoi.org/esc/home

\title{
AN ASSESSMENT OF IMPACT OF INFORMATION AND COMMUNICATION TECHNOLOGY IN ENTERPRIZES OF KORÇA REGION
}

\author{
Rafail Prodani $^{1}$, Jozef Bushati ${ }^{2}$, Aigars Andersons ${ }^{3}$ \\ ${ }^{1}$ University "Fan S. Noli", Bulevardi Rilindasit 11, Korça, Albania \\ ${ }^{2}$ University of Shkodra, "Luigj Gurakuqi", Sheshi 2 Prilli 24, Shkodra, Albania \\ ${ }^{3}$ Vidzeme University of Applied Sciences Latvia, Cesu iela 4, Valmiera, LV-420, Latvia \\ E-mails: ${ }^{1}$ rprodani@yahoo.com, ${ }^{2}$ jozefbushati@gmail.com ${ }^{3}$ aigars.andersons@va.lv \\ Received 18 August 2019, accepted 26 September 2019, published 15 December 2019
}

\begin{abstract}
Ever-evolving and increasingly powerful Information and Communication Technologies (ICTs) have fundamentally changed the nature of global relationships, sources of competitive advantage and opportunities for economic and social development. ICTs have greatly increased the impact on every area of human life. Technologies such as the Internet, personal computers and wireless have turned the globe into a network of individuals, businesses, governments, and ever-growing schools who communicate and interact with one another. Without doubt ICTs plays a strategic role in managing organizations. This paper presents a part of the current state of ICTs for enterprises by establishing comparative bases for further studies in this field. It also helps academic institutions to evaluate and identify factors, as well as the specific role and weight of these factors have in the process of developing ICTs towards a developed economy and society in the context of digital Albania. It is presented as a scientific analyse, accomplished, detailed and expressed in percentage and graphical analysis of a number of very important data sets of enterprises in their full form, to unlock developments in the field of ICTs in our country, including specific ones based on concrete data. This study tends to study the extent to which these but have involved ICTs and what impact these technologies have in the daily work of these organizations in part of Albania (Korca Region)and brings its contribution as a perspective of literature, experience and international studies, the level of development of our country regarding the assessment of electronic readiness of business organizations.
\end{abstract}

Keywords: e-readiness; businesses organizations; information and communication technologies; Internet; impact

Reference to this paper should be made as follows: Prodani, R., Bushati, J., Andersons, A. 2019. An assessment of impact of information and communication technology in enterprizes of Korça region. Insights into Regional Development, 1(4), 334-343. https://doi.org/10.9770/ird.2019.1.4(4)

JEL Classifications: O32

\section{Introduction}

Success nowadays depends on the penetration and impact of Information and Communication Technologies (ICTs) in the society. New ICTs values came into surface and individuals are becoming more and more aware of 


\section{INSIGHTS INTO REGIONAL DEVELOPMENT}

ISSN 2669-0195 (online) http://jssidoi.org/jesi/

2019 Volume 1 Number 4 (December)

http://doi.org/10.9770/IRD.2019.1.4(4)

their usefulness. Changes in attitude and behavior led to new solutions and models that radically changed work in businesses, hospitals, schools, and government.

Technologies such as the Internet, personal computers and wireless telephony have turned the globe into a network of individuals, businesses, governments, and ever-growing schools who communicate and interact with one another (ITG CID Harvard University, 2008). According to theorists of the network society (Castells, 19962000), social structures and activities are increasingly organized around network forms, largely grounded in electronically based information and communication technologies.

In the current technological advancement era that is taking place all over the world, a new kind of rationalization has been introduced into the public sector by the use of modern information and communication technologies (ICT). More and more the use of ICT tools and applications is leading the transformational shifts in the policies, processes and public functions. The electronic government is deciding not only to provide citizen services, but to public sector efficiency goals by improving transparency and accountability to government functions and allowing for cost savings in government administration. ICTs are changing the way the government makes business for the people. In this context, the electronic government seems to be a lever to transform the government.

Getting ready for the network creates many new opportunities for businesses and firms in the developing world by removing barriers for both, information and material goods. Educational institutions and large businesses can extend their activities to this giant network. Governance can become more effective if it extends certain elements of its services to this network. Thus, the benefits of societies in general by the use of this worldwide network are comprehensive both in economic, social and political terms.

Most governments around the globe started their electronic government initiatives with a focus on providing information and services to citizens, while service delivery platforms remain fragmented and parallel across government agencies. In this model, service delivery is built around the functions, structures, information, systems and capabilities of individual action. With the private sector leading the way, access enhancements and greater use of technology have allowed an expansion of new ICT solutions. Now citizens and businesses around the world are increasingly demanding that their governments follow suit. Citizen groups have come to expect a user-friendly interface with ease of use, in a language that the user understands and is tailored to individual needs. The common argument is that intensive use of technology could transform the operational rules of public administration to increase its efficiency, simplify administrative procedures (Fountain, 2006), expand the processes of citizen participation (Hague, 1999) and make government activities more transparent and accountable (Limba et al., 2017).

Our paper is organized as follows: the first part clarifies our use of the concept of "network economy"; it follows with an introduction to the previous state of the business assessment reports on the network and its general characteristics; then assesses the penetration level of business in the network for Korça region, in order to take measures to increase its level. It ends with a synthesis of key findings and points, towards future research topics.

\section{Literature review and methodology}

Preparing for the networked world creates new opportunities for firms and individuals in the developing world, eliminating the traditional barriers of information and goods for developing countries, and promotes efficiency in a variety of activities. Learners can learn more about the world and themselves through the use of the network. Businessmen can find new market opportunities and the most efficient ways to run their firms. Governments can 
provide more efficient public services. Individuals can communicate with friends and family and become more informed about everything in the network.

Participating in the networked world can provide new ways for developing countries to improve their economic, social and political well-being. These opportunities for positive change are increasingly important and accessible as information and communication technologies become more powerful and less costly.

Businesses and governments that are capable of effectively employing information and communication technologies find more sophisticated and efficient ways to manage their external relations and communications.

For assessing the networked economy, we have divided it into two categories. These categories were selected based on several analogous studies in Australia (Australia ICT Data Collection Case Study, 2005) and Greece (eGoverment in Greece, 2016) as well as in the models provided by ITG CID Harvard University (2008), Prodani et al. (2012) and Oxford Analytica (2015), but also relying on the concrete features of our country as well as on the needs and opportunities it has for development. These categories are (figure 1) :

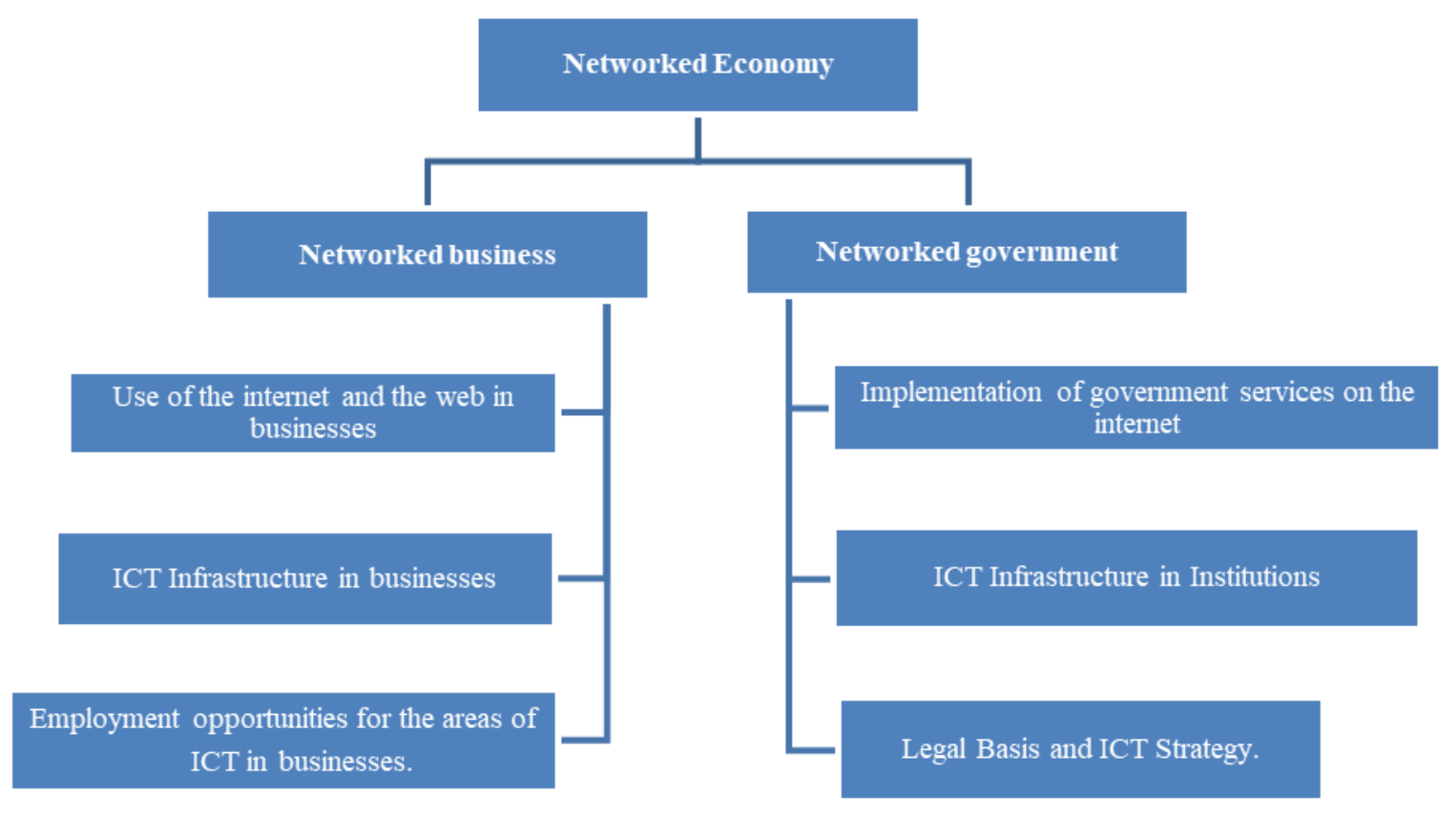

Figure.1. Networked economy

Source: elaborated by the authors based on Australia ICT Data Collection Case Study, 2005; eGoverment in Greece, 2016; ITG CID Harvard University, 2008; Prodani et al., 2012; Oxford Analytica, 2015.

According to Oxford Analytica (2015), Network government is the transition to a more transparent, cooperative and beneficial relationship between government, citizens and business as a result of technological integration and organizational connectivity. By enabling active stakeholder participation and access, it transforms government services by placing users at the center of policy design and implementation, and service delivery. 


\section{INSIGHTS INTO REGIONAL DEVELOPMENT}

ISSN 2669-0195 (online) http://jssidoi.org/jesi/

2019 Volume 1 Number 4 (December)

http://doi.org/10.9770/IRD.2019.1.4(4)

The concept of connected government is derived from the whole-of-governmentapproach which is increasingly looking towards technology as a strategic tool and as an enabler for public service innovation and productivity growth (United Nations, 2008).

The assessment of the network economy is also closely related to the other categories of e-readiness estimates, as network access, networked society and networked education (ITG CID Harvard University, 2008).

Assessing the networked economy is one of the most difficult to estimate if we consider the calculation of other categories of electronic readiness(e-readiness). In this paper, as the part of networked economy is estimated, the calculation is slightly simplified because some of the indicators that are directly related to central governmental factors or that relate to legal factors were not reviewed. We will only deal with modeling of networked business assessment and partial evaluation within our region. This valuation model can be used for similar assessments in developing countries, their characteristics are similar to those of our country.

Porter (1990) determines competitive advantage as the heart of a company's performance. It reflects a company's ability to provide customers with greater value either by lowering prices or offering greater benefits and services that justifies higher prices.

Olugbenga (2006) argues that ICT is being used for strategic management, communication and collaboration, customer access, managerial decision-making, data management and knowledge management as it helps provide an effective tool for organizational productivity and service delivery. Krishnaveni and Meenakumari (2010) claim that ICT has played a major role in reducing operational inefficiency and improving decision-making in many areas of government. Moreover, Hengst and Sol (2001) claim that ICT enables organizations to lower costs, enhance organizational skills, and also assist in the formation of cross-organizational coordination. Therefore, ICT use can help reduce the cost of coordination and increase external resources in organizations. In addition, Irvine and Anderson (2008) comment that the use of ICT provides not only practical benefits to overall management, but also enables companies to overcome place and space disadvantages.

Apulu and Latham (2010), claim that ICT enables customers to get immediate feedback that allows companies to react quickly to customer requests and to recognize new market gaps.

Alam and Noor (2009) argue that ICT provides enterprises with ways to compete globally with improved efficiency and closer relationships with customers and suppliers. Therefore, ICT should be considered by businesses as an important strategy to stay competitive. This implies that organizations that are able to utilize the potentials offered by ICT can address different types of innovative processes in their businesses as ICT influences the performance of an organization in multi-faceted ways. Thus, ICT can bring changes to organizations and make them more competitive, innovative, and help increase organizational growth (Obijiofor et al., 2005).

Case study, is one of the most common methods applied in the Information Systems (SI) field (Alavi et al., 1992). (Sauer, 1993) argues that search in information systems is best done by case studies. The case study method was considered appropriate, as the purpose of the paper is to broaden our understanding of the impact of ICT implementation on businessis. All businesses that are considered are large businesses in our region, with over 10 employees, with typical representatives of all types of businesses and about $2.5 \%$ of them. Data was collected through semi-structured interviews, questionnaires and observations.

The networkedbusiness level in our region will not give it a certain value because the final goal of this study is not to estimate a value for it but to estimate its level as well as to create opportunities to find solutions for improving based on the analysis of several factors that directly affect the online economy. Data is collected in accordance 


\section{INSIGHTS INTO REGIONAL DEVELOPMENT}

ISSN 2669-0195 (online) http://jssidoi.org/jesi/

2019 Volume 1 Number 4 (December)

http://doi.org/10.9770/IRD.2019.1.4(4)

with International Telecommunication Union (ITU) standards, according to (Core List of ICT Indicators, 2016), Eurostat indicators for evaluation digital ecomony and similar studies in other countries.

\section{Research results}

In Korça region and in Albania before 1990 there was no industry for the production of equipment and software related to ICTs but even after the 90s during the economic transition period we did not have a significant development in these areas.Businesses and other private and state institutions have implemented too late new digital technologies, showing a tendency towards ignoring these technologies. This was due to lack of knowledge about ICT fields by employees and executives of that time. A major implementation of these technologies was observed after 2000 when the implementation of new technologies became irreplaceable and an important factor of competition between businesses. It became irreplaceable because the volume of work grew and the actions were very difficult to carry out manually, the quality and performance of work with computers is significantly greater, competition between businesses became stronger and the impetus for ICT implementation was coming and increased by government institutions. An important factor for the implementation of ICT in businesses and state institutions is also the Internet. Communicating and receiving various information via the internet was at the beginning a good impetus for the introduction of the Internet into state institutions and bussinesis. The situation has changed completely with the release of Web 2.0, 3.0 or semantic web. Introducing the Web to a variety of government services, creating opportunities to make financial transactions on the web, buying opportunities and establishing business-to-business relationships on the web have made the implementation of Internet technologies a need and a duty for every institution and business.

So, a greater implementation of these technologies was observed after year 2000 when the implementation of new technologies became an important factor of competition between businesses. While after 2010, with the introduction of ADSL, Fiber Optics, WIMAX and 4G technologies, we are seeing an ever-increasing implementation.

Let's analyze one by one the indicators of netword business category:

1. The percentage of businesses that have been using computers and internet during the last year is $90 \%$ for both. There is an increase in comparison to $62 \%$ and $52 \%$ for computers and internet in the year 2012, see (R. Prodani et al, 2012). This is because of the real growth of online government services, low cost broadband internet, implementation of technologies such as Adsl, Fibber Optic, 4G, use of smartphones and other devices on the Internet.

2. The percentage of people employed in businesses which work regularly on computers in our region is smaller if we take into account the level of developed countries. The value of this indicator is $25 \%$, somehow higher than the $19 \%$ value that was in 2012, see (Prodani et al, 2012).

3. The percentage of regular internet users in Korça region businesses is $23 \%$. This percentage for our region in 2012 was about $12 \%$. This seems an increase not too small but comparable with developing countries where this percentage goes above $50 \%$.

4. Nowadays the implementation of networked businesses is an important factor that guarantees the success of the business. If we take into account the various internet services provided, such as a website, social networks etc. where we can put all the information necessary for business operation. At the moment when this study started, Korca's businesses have a web presence of $50 \%$. We have a big increase compared to the $5 \%$ we had at the beginning of 2012, see (Prodani et al, 2012).

5. The percentage of businesses in Korca region with Intranet is about $10 \%$. We have to be optimistic about this value if we take into consideration the short period of these technologies are present in our city. Intranet has 


\section{INSIGHTS INTO REGIONAL DEVELOPMENT}

ISSN 2669-0195 (online) http://jssidoi.org/jesi/

2019 Volume 1 Number 4 (December)

http://doi.org/10.9770/IRD.2019.1.4(4)

mostly second level banks and, as far as other businesses are concerned, they do not have the necessary capacity to apply such technology. The study conducted in 2012 on intranets in the Korca region businesses almost did not speak at all. In this survey, businesses with LAN accounted for about $20 \%$ of large businesses, whereas today they go to $90 \%$.Another important indicator that impacts the largest involvement of large businesses and their networking activities is the type of internet installed in them. In 2012 only $31 \%$ of businesses interviewed had access to the internet broadband while today $90 \%$ of interviewed businesses had such internet, using technologies such as ADSL 30\%, Fibber Optic 60\%, 4G 10\%.

6 . There are a growing percentage of businesses offering online products. In the study conducted in 2012 , only $2 \%$ of the businesses interviewed carried out online sales. While today this percentage has gone to almost $10 \%$. This indicator in the European Union countries in 2017 is worth 18\%, see (Eurostat-Ecommerce sales, 2017). We are optimistic, although we have to mention that the clients of these businesses are not far from the geographic location of the latter ones. They usually prefer to order their product directly from business wholesale sites. We can expect that this indicator will increase in parallel with Korca's businesses increase which will bring to a growing number of clients. This can be achieved by creating a website, displaying different products on catalogs and receiving client orders online. Providing various services online requires the business staff and IT managers training in implementing the new technologies and knowing the advantages and disadvantages of internet services.

7. Extranets are widespread in banks and large companies. The connection of businesses by extranet is typical of contexts when such businesses trade with each other online, usually through the internet being isolated from the other part of it. This type of commerce is named B2B to the business network and some of its advantages are related to the fact that communication between businesses becomes easier and less costly, payments are faster and transparency is generally bigger. The number of these businesses in Korça is very limited, only a few banks, therefore the value of this indicator is very low about $2 \%$.

8. The indicator that shows the Internet business activities is one of the most interesting ones to follow because it basically informs us on how the business uses the internet. The more computerized public institutions are, and the broader range of services they offer, the greater the collaboration of businesses with them will be. So the number of businesses using online government services has increased a lot. The percentage of businesses receiving information from online government services is about 55\%, while the percentage of businesses interacting with them is $45 \%$. Growth is also noticed in the percentage of businesses purchases online, is around $18 \%$. It is a big increase if we consider the 5\% value that this indicator had in the 2012 survey. In European Union countries this value goes to $26 \%$, see (Eurostat, 2017b). Let's look at figure 2: 


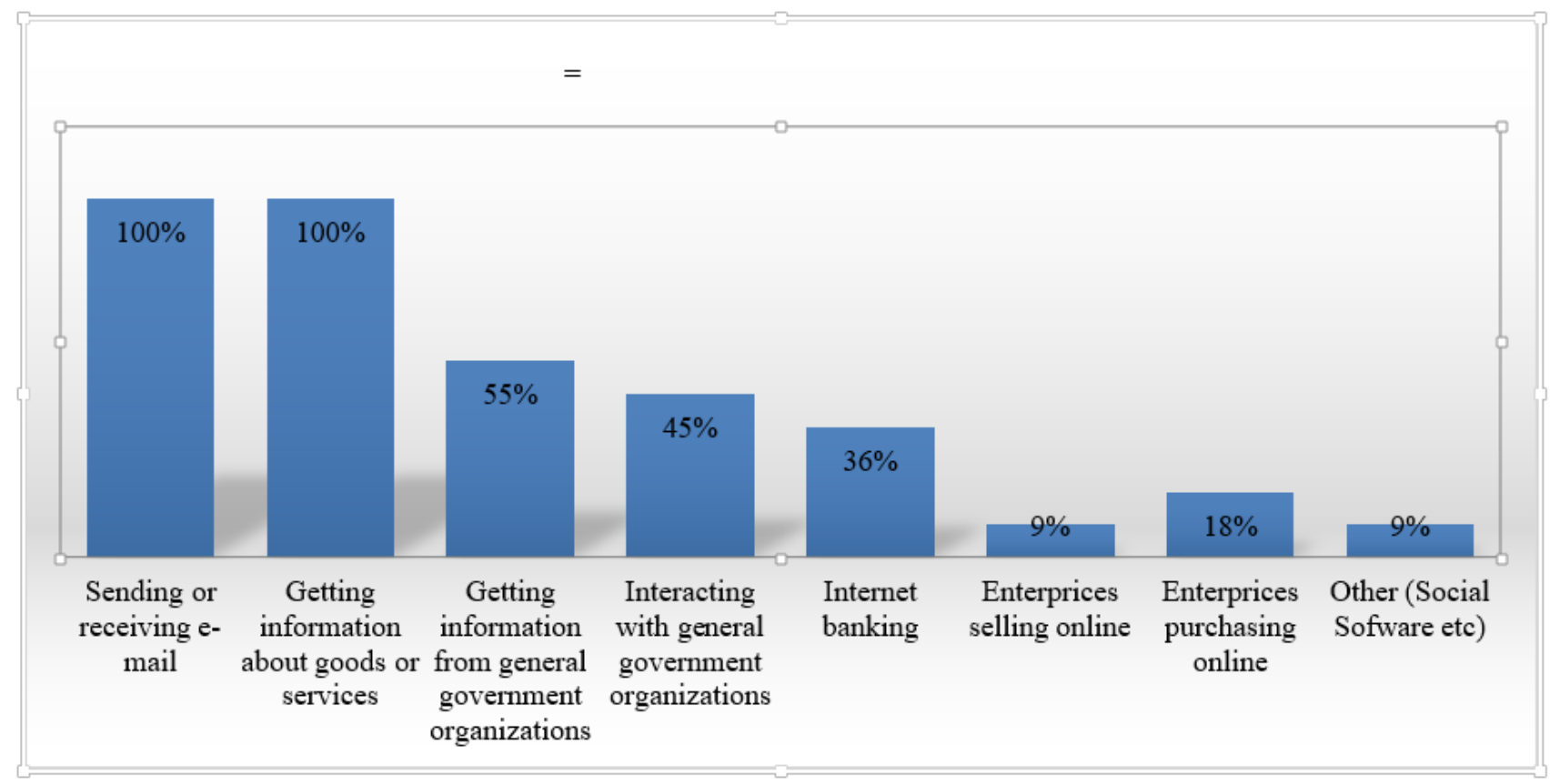

Figure 2. Proportion of businesses using Internet by activity Source: Eurostat, 2017b.

\section{Conclusions}

The IT infrastructure of the businesses of our region has gone through a rapid development during the last few years. This same period has witnessed the implementation of a great number of online government services related to businesses and we think that the penetration of businesses to the network is tending to reach maximum levels.

There has been growth in almost all the indicators of this category and this has happened for several reasons. The first reason is the liberalization of the Internet distribution market, the introduction of technologies such as ADSL, Fiber Optic, 4G etc. Another reason is the implementation of many government services in the internet such as online tax system, building permits, obtaining certificates, online tenders, etc. all incorporated in the e-Albania portal. Fullanteli and Allegra (2003) emphasize that ICT provides enterprises with a wide range of opportunities to improve their competitiveness and provides mechanisms for access to new market opportunities. Also (Fink and Disterer, 2006) also advocate that ICT provides many potential benefits to organizations in order to make them more efficient, effective and competitive.

From the interviews with managers of different companies we also have noticed these direct reasons that could get businesses in our region to incorporate the modern technologies into their business: competition and effectiveness at work. This implies that organizations need to invest in ICTs to stay independent of their competitors and also to give them a sustainable competitive advantage and also to increase efficiency at work.

Despite these achievements, businesses in European Union countries are far ahead in the implementation of internet technologies especially IoT(Internet of Things) systems. What emerged from the conversations that we had with heads of local businesses, was the need of regional businesses for qualified specialists in the new ICTs fields, especially those that are connected to the Internet technologies. These specialists will be aware of the 
INSIGHTS INTO REGIONAL DEVELOPMENT

ISSN 2669-0195 (online) http://jssidoi.org/jesi/

2019 Volume 1 Number 4 (December)

http://doi.org/10.9770/IRD.2019.1.4(4)

further benefits that these businesses may have from applying new ICTs and will help these businesses apply these technologies.

Implementing ICTs in businesses also brings about organizational and structural changes in them, this is a challenge that businesses and government institutions have to face.

To increase the level of ICTs involvement in businesses we can give two basic recommendations:

1) Awareness of business managers and owners about the benefits of ICTs implementation, information about the latest ICTs and the creation of opportunities to have the most skilled professionals in the ICTs field.

2) Creating opportunities to include the IoTsystem in businesses, between businesses, and perhaps even wider.

We can say that today we are moving from the first phase characterized by good internet and computer access to businesses, low level of network services in them, and poor use of ICT in assisting the process work in institutions and manufacturing in the second phase where we have a new inclusion of new ICT technologies in the work and production process, the implementation of most of the network services supported by skilled specialists in ICT fields where the vast majority of transactions with government institutions and businesses are carried out on the Internet.

This study will be useful to entrepreneurs, policy makers especially in developing countries, as well as researchers who are interested in ICTs development because the study helps to identify ICTspenetration and impact in businesses, the ways to take for increasing its level of involvementin businesses as well as some of the positive effects that this involvement has.

\section{References}

Alavi, M.; \& Carlson, P. 1992. A review of MIS research and disciplinary development. Journal of Management Information Systems 8(4): 45-62. https://doi.org/10.1080/07421222.1992.11517938

Apulu, I.; \& Latham, A. 2010. Benefits of information and communication technology in small and medium sized enterprises: a case study of a Nigerian SME. UK Academy for Information Systems Conference Proceedings 7. Retrieved from http://aisel.aisnet.org/ukais2010/7

Castells, M. 1996-2000. La Era de la Informacin (trilogy). Madrid, Spain: Alianza.

Eurostat. 2017a. Digital Ecomony and Society, E-commerce sales. Retrieved from

http://appsso.eurostat.ec.europa.eu/nui/submitViewTableAction.do

Eurostat. 2017b. Digital Ecomony and Society, E-commerce purchases. Retrieved from

http://ec.europa.eu/eurostat/tgm/table.do?tab=table\&init=1\&language=en\&pcode=tin00112\&plugin=1.

Fink, D.; \& Disterer, G. 2006. International case studies: To what extent is ICT infused into the operations of SMEs. Journal of Enterprise Information 19(6): 608-624. https://doi.org/10.1108/17410390610708490

Fountain, J. 2006. Central issues in the political development of the virtual state, in Castells, M.; \& Cardoso, G. (Eds.). The Network Society: From Knowledge to Policy. Washington D.C., USA: Brookings Institution Press, 149-182.

Fulantelli, G.; \& Allegra, M. 2003. Small company attitude towards ICT based solutions: Some key-elements to improve it. Educational Technology and Society 6(1). Retrieved from https://pdfs.semanticscholar.org/c636/5125c99760961fc7d3ca6be1754071f1f043.pdf.

Hague, B.; \& Loader, B. D.1999. Digital Democracy: Discourse and Decision Making in the Information Age. London, UK: Routledge.

Hengst, M.; \& Sol, H. G. 2001. The impact of information and communication technology on interorganizational coordination: Guidelines from theory. Informing Science 4(4). https://doi.org/10.28945/567 


\section{INSIGHTS INTO REGIONAL DEVELOPMENT}

ISSN 2669-0195 (online) http://jssidoi.org/jesi/

2019 Volume 1 Number 4 (December)

http://doi.org/10.9770/IRD.2019.1.4(4)

Irvine, W.; \& Anderson, A. R. 2008. ICT (information communication technology), peripherality and smaller hospitality businesses in Scotland. International Journal of Entrepreneurial Behaviour \& Research 14(4): 200 - 218. https://doi.org/10.1108/13552550810887381

ITG CID Harvard University. 2008. Readiness for the Networked World. A Guide for Developing Countries. Retrieved from https://cyber.harvard.edu/readinessguide/

ITU. 2005. Australia: ICT Data Collection Case Study. International Telecommunication Union Place des Nations CH-1211 Geneva Switzerland. Retrieved from https://www.itu.int/itudoc/gs/promo/bdt/cast_int/87587.pdf

ITU. 2016. Core List of ICT Indicators,. Partnership on Measuring ICT for Development. Retrieved from https://www.itu.int/en/ITUD/Statistics/Documents/coreindicators/Core-List-of-Indicators_March2016.pdf

Krishnaveni, R.; \& Meenakumari, J. 2010. Usage of ICT for information administration in higher education institutions - A study. International Journal of Environmental Science and Development 1(3): 43-61. https://doi.org/10.7763/IJESD.2010.V1.55

Limba, T.,; Agafonov, K.; Paukštè, L.; Damkus, M.; Plèta, T. 2017. Peculiarities of cyber security management in the process of internet voting implementation. Entrepreneurship and Sustainability Issues 5(2): 368-402. http://doi.org/10.9770/jesi.2017.5.2(15)

Obijiofor, L.; Inayatullah, S.; \& Stevenson, T. 2005. Impact of new information and communication technologies (ICTs) on the socioeconomic and educational development of Africa and the Asia-Pacific region. Paper Presented at the 3rd Working Conference on Information and Communications Technology Solutions for Government Operations, E-government and National Development. African Regional WSIS PrepCom Pre-Event, Accra International Conference Centre, Accra, Ghana, 27-28 January.

Olugbenga, F. I. 2006. Strategic application of information and communication technology for effective service delivery in an organisation. Proceedings of the 6th Global Conference on Business and Economics. GUTMAN Business Center, USA, 18-23.

Oxford Analytica. 2015. Networked Goverment The Transition to Citizen Centricity. A Report in Collaboration with the Government Summit. Retrieved from https://www.oxan.com/media/1315/networkedgovernment-oxfordanalytica.pdf

Porter, M. E. 1990. The Competitive Advantage of Nations. London, UK: Macmillan.

Prodani, R.; Çeliku, B.; Pema, E.; \& Kotori, M. 2012. Assessment of Networked Businees. Case study: Korça city. Proceedings book of the CONFERENCE III "Information systems and technology Innovation their application in Economy" Faculty of Economy, University of Tirana, 112-119.

Sauer, C. 1993. Why Information Systems Fail: A case Study Approach. Henley-on-Thames, UK: Alfred Waller Ltd.

United Nations. 2008. The Global Information Society: A Statistical View. Retrieved from http://www.itu.int/ITUD/ict/material/LCW190_en.pdf

Waksberg-Guerrini, A.; \& Aibar, E. 2007. Towards a network government? A critical analysis of current assessment methods for egovernment. International Conference on Electronic Government, EGOV 2007: Electronic Government: $330-341$. https://doi.org/10.1007\%2F978-3-540-74444-3_28 
INSIGHTS INTO REGIONAL DEVELOPMENT

ISSN 2669-0195 (online) http://jssidoi.org/jesi/

2019 Volume 1 Number 4 (December)

http://doi.org/10.9770/IRD.2019.1.4(4)

Rafail PRODANI

ORCID ID: 0000-0001-9594-9662

Josef BUSHATi

ORCID ID: 0000-0002-7058-2558

Aigars ANDERSONS

ORCID ID: 0000-0002-9079-7097

Register for an ORCID ID:

https://orcid.org/register

Copyright (C) 2019 by author(s) and VsI Entrepreneurship and Sustainability Center

This work is licensed under the Creative Commons Attribution International License (CC BY).

http://creativecommons.org/licenses/by/4.0/

(c) (i) Open Access 